MARHAROAN BOLON:

\title{
KOREOGRAFI YANG TERINSPIRASI DARI PESTA ADAT MASYARAKAT BATAK SIMALUNGUN
}

\author{
Desy Wulan Pita Sari Damanik; Dindin Heryadi; Sri Hastuti
}

Jurusan Tari, Fakultas Seni Pertunjukan, Institut Seni Indonesia Yogyakarta

Email: echyedamanik@gmail.com; dinheryadi@gmail.com; tutibdg57@gmail.com

\section{RINGKASAN}

Marharoan Bolon diambil dari bahasa Batak Simalungun yaitu Marharoan yang berarti bekerja, kata Bolon adalah besar. Jika diartikan keduanya Marharoan Bolon berarti bekerjasama atau gotong royong. "Marharoan Bolon" merupakan karya tari yang terinspirasi dari pesta Rondang Bittang, yaitu Pesta adat masyarakat Simalungun setelah musim panen untuk mengungkapkan rasa syukur atas keberhasilan panen raya dengan menggunakan berbagai tata cara ritual sebelum pesta dimulai. Pesta Rondang Bittang memiliki nilai kerja sama dan saling gotong royong. Sama seperti halnya makna yang terkandung dalam motif gerak mangunje mangodak, dan nahei kaki yaitu gerak yang menyilangkan tangan dan kaki. Silang memiliki makna persatuan, kerjasama dan saling gotong royong. Karya Marharoan Bolon merupakan koreografi kelompok yang terdiri dari delapan orang penari perempuan, jumlah delapan penari kerena akan tetap genap jika dibagi menjadi dua kelompok. Busana dalam koreografi ini menggunakan bahan Hiou dan pilihan warna lebih pada warna merah, hitam dan putih, ketiganya merupakan warna yang digunakan dalam setiap kegiatan adat Batak. Musik tari diformat MIDI dengan pola-pola hasil pengembangan Gondrang parrahot dan Gondrang Sipitu-pitu Batak Simalungun. Metode penciptaan dalam karya ini menggunakan metode eksplorasi sebagai bagian awal dalam pengembangan kreativitas proses penciptaan, improvisasi untuk menemuan gerak secara kebetulan atau spontan, komposisi untuk melakukan penyusunan gerak gerak yang telah didapat, serta evaluasi mengoreksi secara berkala terhadap proses. Pesan yang ingin disampaikan dalam karya ini adalah sebagai manusia yang hidup di jaman sekarang tetaplah mempertahankan rasa saling membantu dan bekerja sama terhadap orang lain.

Kata kunci: Pesta Rondang Bittang, Kerja Sama, Tari Kelompok 
JOGED: Jurnal Seni Tari p-ISSN 1858-3989 | e-ISSN 2655-3171
MARHAROAN BOLON:

KOREOGRAFI YANG TERINSPIRASI

DARI PESTA ADAT MASYARAKAT BATAK SIMALUNGUN

\begin{abstract}
Marharoan Bolon is a term of Batak Simalungun's language, Marharoan means work and Bolon means big. So Marharoan Bolon has a meaning of work together or cooperate. "Marharoan Bolon" is a works of dance inspired by the Rondang Bittang party, the traditional thanks giving party of Simalungun's indigenous to the god on successed in harvest season, and it requires some kind of rituals before be held. The Rondang Bittang party has the value of mutual cooperation. As well as it is contained in mangunje mangodak and nahei kaki motion motive, the motion of of cross the legs and arms. The cross motion has the meaning of union and cooperation. This meaning was raised to be dance a performance based on Batak Simalungun's tradition. Marharoan Bolon is the choreography in a group from consists of eight female dancers. It will be still even when divided into two groups. The costume is made by Hiou material in red, black and white, as dominant selected colour. Those three of colour are always used in any Batak Simalungun's tradition. The music is made by MIDI programe with the development Gondrang parrahot and Gondrang Sipitu-pitu patterns. The method of this creation is using an exploration method as the beginning part creativity development of the creation process, the improvisations for discovering motions spontaneously, and the composition for arranging the discovered. The message motions of this dance performance remind us as human being for preserving the value of mutual cooperate in nowadays era.
\end{abstract}

Keywords: Rondang Bittang Party, Cooperate, dance group.

\title{
1. PENDAHULUAN
}

Indonesia adalah negara yang memiliki berbagai suku bangsa yang berbeda-beda dari Sabang sampai Merauke. Sumatera Utara merupakan salah satu Provinsi yang ada di Indonesia yang mempunyai adat istiadat serta budaya yang sampai saat ini masih dilestarikan dan dijaga keindahannya. Salah satu suku yang ada di Sumatera Utara adalah suku Batak. Batak terbagi menjadi 5 suku yaitu, Batak
Toba, Batak Simalungun, Batak Pakpak, Batak Karo dan Batak Mandailing/Angkola. Begitupun dengan kesenian-keseniannya memiliki ciri khas masing-masing. Salah satunya suku Batak Simalungun yang berada di Kabupaten Simalungun, memiliki kesenian tari tradisi yang sampai saat ini masih diajarkan pada generasi muda yang berada di Provinsi Sumatera Utara Kabupaten Simalungun. 
Salah satu tari yang ada di Provinsi Sumatera Utara, Kabupaten Simalungun adalah tari Manduda. Tari ini diciptakan pada tahun 1957 oleh Taralamsyah Saragih seorang seniman Batak yang lahir pada hari Ahad, 18 Agustus 1918 di Pamatang Raya, Kabupaten Simalungun. Kata Manduda dalam bahasa Batak Simalungun berarti menumbuk padi. Tari ini menceritakan tentang kehidupan petani wanita yang sedang turun ke sawah dengan suasana gembira, mulai dari menanam padi sampai menuai padi. Tari Manduda sudah mentradisi sebagai hasil dari pembawaan gaya masyarakat itu sendiri. Dalam menarikannya terdapat teknik-teknik gerak yang merupakan aturan dari gerak-gerak Tari Manduda. Gerak memotong padi, mengirik, dan menampis padi tergambar melalui motif-motif gerakannya yang lemah gemulai dan lincah. Beberapa nama motif gerakan tari Manduda yaitu mangunje mangodak adalah gerakan kedua tangan menyilang di depan dada dan kedua tangan di sisi kiri dan kanan dengan membolak-balikkan telapak tangan; ser-ser adalah gerakan bergeser dengan cara membuka tutup telapak kaki (dalam bahasa Jawa disebut kengser); menapih padi adalah gerakan timpuh sambil memegang suri-suri; membuka roha adalah gerakan timpuh badan condong ke depan sambil mangodak ke kiri dan ke kanan; nahei kaki adalah gerakan silang kaki sambil memegang suri-suri; manduda adalah gerakan khas dari tarian ini yang gerakannya seperti menumbuk padi menggunakan losung/ lesung; dan ondok adalah gerakan dengan menekukkan kaki ke depan seperti hendak menjatuhkan pinggul dan kembali tegak, dilakukan secara berulang-ulang.

Di antara salah satu motif tersebut yang menarik perhatian penata adalah gerak Mangunje Mangodak dan nahei kaki.

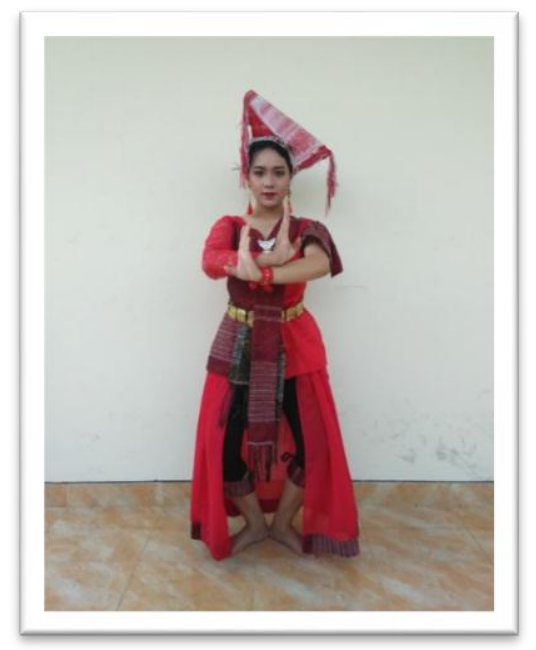

Gambar 1: Sikap tari pada motif mangunje mangodak pada hitungan sa- dari hitungan satu, tangan menyilang di depan dada (Foto, Desy Wulan Pita Sari Damanik.2017)

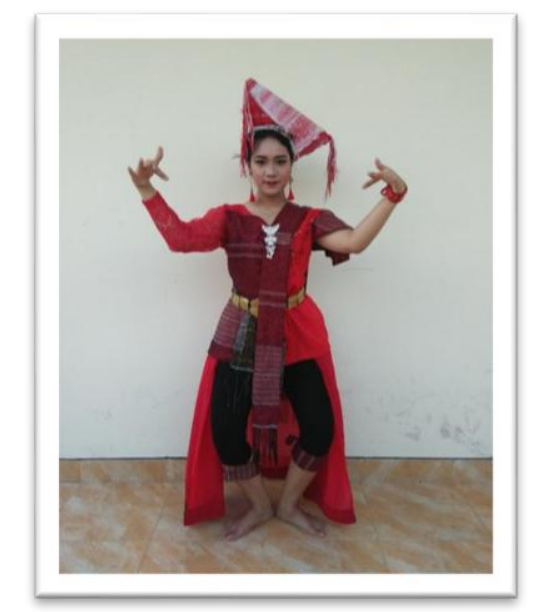

Gambar 2: Sikap taripada motif mangunje mangodak pada hitungan -tu dari hitungan satu, tangan membuka dari persilangan di depan dada. (Foto: Desy Wulan Pita Sari Damanik.2017) 
JOGED: Jurnal Seni Tari

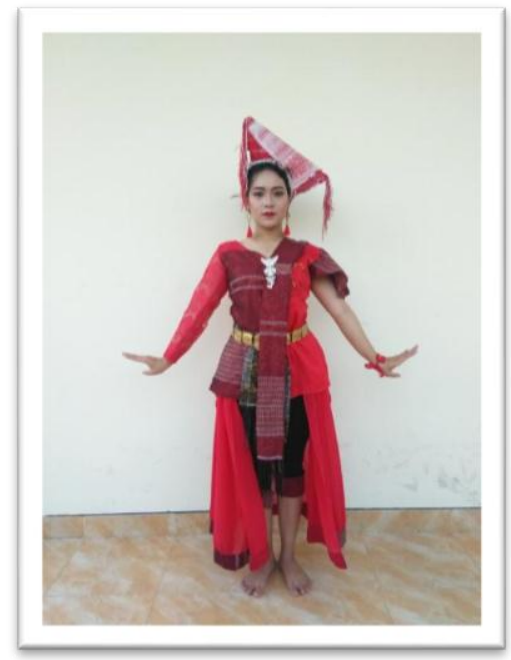

Gambar 3: Sikap tari pada motif mangunje mangodak pada hitungan du- dari hitungan dua, tangan berada di kiri kanan badan, telapak tangan menghadap kebawah. (Foto: Desy Wulan Pita Sari Damanik.2017)

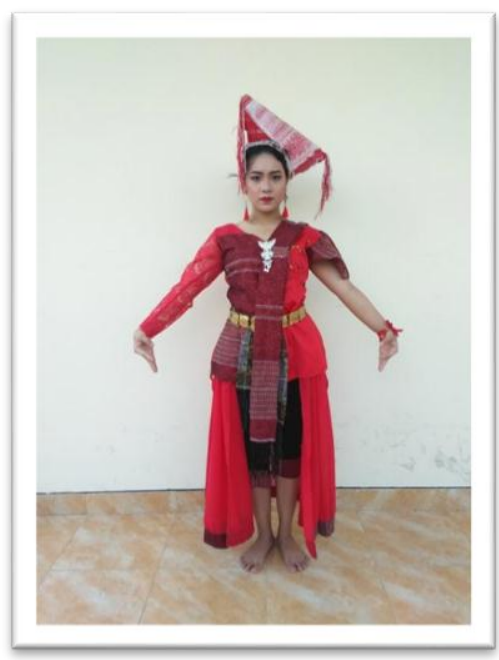

Gambar 4: Sikap tari pada motif mangunje mangodak pada hitungan diantara du- dan -a dari hitungan dua, tangan berada di kiri kanan badan, telapak tangan menghadap keatas. Lalu hitungan -a dari dua telapak tangan menghadap bawah. (Foto:DesyWulan Pita Sari Damanik.2017)

Motif gerak mengunje mengodak menjadi salah satu gerak yang menarik perhatian karena iringan Musiknya yang khas. Deskripsi Mangunje Mangodak: kedua tangan menyilang di depan dada, kemudian dibuka
MARHAROAN BOLON: KOREOGRAFI YANG TERINSPIRASI DARI PESTA ADAT MASYARAKAT BATAK SIMALUNGUN

lalu membuka ke samping dengan membolakbalikkan kedua telapak tangan. Selain itu, motif gerak nahei kaki juga mencuri perhatian dikarenakan permainan kaki yang sangat unik. Permainan kaki yang harus digerakkan dengan menyilang ke kiri atau ke kanan. Menyilang memiliki makna bekerja sama. Hal yang menjadi perhatian dari gerak kaki nahei kaki tersebut adalah ketika telapak kaki saling bergantian menyentuh lantai berjalan ke samping kiri atau ke samping kanan. Gerak bergantian saling mengisi dan sikap menyilang dalam bergerak ini mendorong imaji kreatif dalam menciptakan karya tari tersebut untuk dipindahkan ke tubuh penari sehingga kemungkinan tercipta gerak baru yang diambil dari esensi motif nahei kaki.

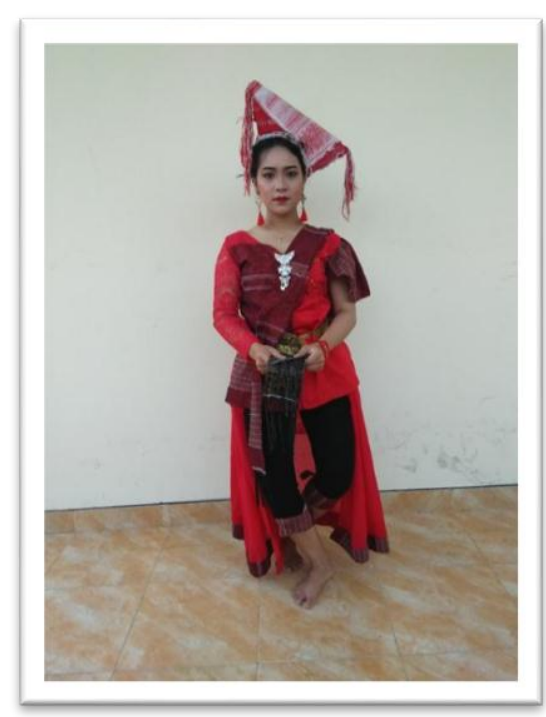

Gambar 5: Sikap tari pada motif nahei kaki yaitu gerakan silang kaki ke samping kiri atau kanan (Foto, Desy Wulan Pita Sari Damanik.2017) 
Motif gerak Mangunje Mangodak dan Nahei kaki menjadi motif yang sangat menarik perhatian karena motif gerak tersebut tampak konsep persatuan, penggabungan, kerja sama, dan saling mengisi. Dalam menyampaikan makna dari karya tari ini dibutuhkan gerak simbolis melalui motif-motif gerak tersebut. Karya tari ini, selain mengembangkan motifmotif tari Batak Simalungun juga terinspirasi dari pesta Rondang Bittang yang memiliki makna kerja sama dan gotong royong pada masyarakat Batak Simalungun. Hubungan kekerabatan orang Batak memiliki pertalian darah atau perkawinan yang telah dijadikan alasan orang Batak untuk saling bersikap ramah. ${ }^{1}$ Hal ini terkadang mendatangkan keuntungan serta ada rasa untuk saling membantu satu sama lain. Sistem kekerabatan ini yang membentuk kekeluargaan dalam masyarakat Batak Simalungun dalam hubungan sosial, serta muncul sikap sosial saling membantu dalam setiap kegiatan termasuk bercocok tanam, memanen, dan melakukan pesta panen (Marondang Bittang). Arti kata Rondang Bittang adalah terang benderang. Kata rondang yang berarti terang, kata Bittang yang berarti benderang, melebihi terang yang biasa. Itu sebabnya pesta Rondang Bittang biasanya digelar pada malam hari di saat bulan purnama. Acara
Pesta Rondang Bittang diawali dengan Mamuhun, yang maknanya meminta ijin pada Keturunan Raja Simalungun untuk melaksanakan adat, sebelum panen dimulai.Kemudian para wanita melakukan kegiatan Maranggir (pembersihan diri), dengan membesihkan badan, hati, dan pikiran dengan menggunakan jeruk purut. Terakhir Marpakean Adat (berpakaian adat), semua masyarakat dalam melakukan pesta Rondang Bittang, wajib memakai pakaian adat Simalungun. Tujuannya agar dewasa dalam seluruh aspek kehidupan.

Kedua motif gerak dan kerjasama dalam pesta rondang bittang menjadi dasar dalam menciptakan karya tari ini. Penciptaan koreografi kelompok yang didasari oleh gerak Mangunje Mangodak, nahei kaki dan ritual pesta Rondang Bittang ditarikan oleh 8 penari Putri. Karya tari ini mencari kemungkinan gerak-gerak baru yang bersumber dari esensi gerak Mangunje Mangodak dan Nahei kaki dengan ruang, waktu, tenaga, aksi dan diperkuat dengan ritual pesta Rondang Bittang.
1 JC Vergouwen. 2004. Masyarakat Dan Hukum Adat Batak Toba. Yogyakarta: LKiS Yogyakarta. 6. 
JOGED: Jurnal Seni Tari

p-ISSN 1858-3989 | e-ISSN 2655-3171

\section{PEMBAHASAN}

\section{A. Konsep Penciptaan Tari}

Proses penggarapan karya tari ini menggunakan rangsang visual. Rangsang visual berawal dari melihat para penari menggerakkan motif gerak Mangunje Mangodak dan nahei kaki serta pengalaman sendiri dalam menggerakkan motif gerak tersebut. Permainan tangan, koordinasi tangan, dan kaki serta naik-turunnya tubuh yang dilakukan dengan begitu indah mendorong imaji kreatif. Selain rangsang visual, juga terdapat rangsang idesional dalam karya ini karena dengan merasakan setiap pengalaman yang terjadi di kehidupan seseorang yaitu pengalaman bagaimana melihat kerja sama masyarkat Simalungun ketika mengadakan ritual pesta Rondang Bittang. Pesta Rondang Bittang menjadi inspirasi dalam menciptakan tari yang akan dituangkan mewakili realita, disimbolkan dan ekspresikan melalui gerak.

Tema tari karya ini bersifat literal, karena penyajian karya tari ini berceritera. Tema karya tari ini adalah kerja sama. Penata memberi judul pada karya ini adalah Marharoan Bolon, Marharoan diambil dari bahasa Batak Simalungun dari kata Haroan yang berarti kerja, kata Bolon adalah besar. Jika diartikan keduanya Haroan Bolon yang berarti kerjasama atau gotong royong. Hubungan
MARHAROAN BOLON: KOREOGRAFI YANG TERINSPIRASI DARI PESTA ADAT MASYARAKAT BATAK SIMALUNGUN

judul dengan garapan adalah karya ini mengembangkan motif gerak mangunje mangodak serta memvisualisasikan kerja sama dalam pesta Rondang Bittang. Sehingga penata memilih kata Marharoan Bolon sebagai judul dari karya ini. Selain tipe studi karya tari ini juga memiliki tipe tari dramatik.

Mode penyajian karya tari ini adalah simbolis representasional. Simbolis karena dalam karya tari ini gerak yang muncul kadang tidak dikenali makna geraknya. Simbolik pada karya ini divisualkan dengan menggunakan pose-pose dan gerak tradisi Batak Simalungun. Sedangkan representasional karena dalam karya tari ini menggambarkan sesuatu kenyataan sesuai dengan gerak kesehariannya yang telah distilisasi. Konsep garapan yang digunakan adalah konsep garapan tradisi gerak tari Batak Simalungun.

Karya tari ini berpijak pada gerak tari tradisional Batak Simalungun yaitu motif gerak Mangunje Mangoda dan nahei kaki pada tari Manduda. Karya tari ini akan ditarikan oleh 8 penari berjenis kelamin perempuan.

Penari ini akan dikomposisikan dalam sebuah kompisisi kelompok besar dan kelompok kecil dengan memperhatikan penyusunan bagian. Di samping itu penari 
MARHAROAN BOLON:

KOREOGRAFI YANG TERINSPIRASI

JOGED: Jurnal Seni Tari

DARI PESTA ADAT MASYARAKAT BATAK SIMALUNGUN p-ISSN 1858-3989 | e-ISSN 2655-3171

dalam bentuk genap penggunaan pola lantai sebagai simbolisasi dari kerja sama dan persilanngan yang dominan simetris.

Pertimbangan penari yang berjenis kelamin perempuan karena karya ini terinspirasi dengan petani wanita dalam tari Manduda, kedua sebagai simbolis dari persilangan yang simetris. Penata akan menyajikan format MIDI (Musical Instrument Digital Interface) sebagai iringan tarinya. Alat musik yang digunakan terdiri dari ogung, ogung adalah alat musik khas Simalungun seperti gong, gonrang adalah gendang khas Batak Simalungun, sarunei adalah alat musik tiup, dan sulim adalah flute yang terbuat dari bambu.

Tata busana berpijak dari tata busana adat Batak Simalungun, terbuat dari kain Hiou/Ulos yang berwarna merah. Busana yang digunakan dalam karya ini adalah busana asli Batak Simalungun yang sudah dikembangkan. Busana Batak Simalungun yang sudah dikembangkan adalah baju lengan panjang sama seperti busana sebelumnya, menggunakan bahan yang terbuat dari Hioul Ulos Simalungun agar memberi kesan bahwa tarian ini berasal dari Simalungun, Sumatera Utara.

Pemanggungan yang digunakan dalam karya karya tari ini adalah di panggung pertunjukan yang tertutup dapat dilihat dari satu arah penonton yaitu proscenium stage, dan lokasi pementasan di Jurusan Tari Fakultas Seni Pertunjukan Institut Seni Indonesia Yogyakarta. Konsep yang akan diterapkan dalam pementasan dapat tersampaikan dengan adanya jarak, sehingga dapat dilihat secara fisikal. Fungsi tata cahaya dalam karya tari adalah mendukung aspek visual. Pada karya ini pencahayaan menunjukkan suasana tertentu, seperti suasana pedesaan, selain itu cahaya berfungsi sebagai penonjolan baik rias maupun busana yang dikenakan penari. Tata rupa pentas karya tari ini menampilkan adegan panen dan pesta panen dengan menghadirkan bantuan setting dengan membuka backdrop, Pada awal dan akhir pertunjukan menggunakan trap yang disusun di balik backdrop, dengan ukuran 2x1 empat buah trap, sebagai simbol suasana tempat yang baru yang diwujudkan dalam ruang yang berbeda dari adegan lainnya. Selain itu, pada karya ini menggunakan beras sebagai setting akhir dari karya ini sebagai simbol pesta panen. Beras akan dijatuhkan dari atas menghujani para penari di stage. Ada pula properti yang digunakan dalam tari ini adalah Anduri. Anduri (dalam bahasa Batak Simalungun) adalah benda sebagai wadah beras yang terbuat dari rotan atau bambu. 
JOGED: Jurnal Seni Tari p-ISSN 1858-3989 | e-ISSN 2655-3171

\section{B. Metode Penciptaan Tari}

1. Eksplorasi

Eksplorasi dipahami sebagai suatu cara berpikir, berimajinasi, merasakan dan merespons objek-objek dan fenomena alam yang ada, dijadikan sebagai bagian awal dalam pengembangan kreativitas proses penciptaan. Eksplorasi dalam proses penciptaan karya "Marharoan Bolon" dimulai dengan mengumpulkan sumber data tertulis atau video yang berkaitan dengan objek yang dijadikan sumber berkarya yaitu Rondang Bittang. Hal ini dilakukan untuk memunculkan imajinasi dan membangun kreativitas berrpikir dalam menentukan banyak hal seperti: menemukan pengembangan motif Mangunje Mangodak dan nahei kaki, sebagai pola gerak dasar dari garapan ini, menemukan desain kostum, pemilihan properti yang digunakan untuk mempresentasikan kerja sama, dan pengembangan musik iringan yang berpijak pada pola musik Gondrang Parrahot dan Gondrang Sipitu-pitu.

\section{Improvisasi}

Improvisasi dapat diartikan sebagai penemuan gerak secara kebetulan atau spontan, walaupun

\footnotetext{
${ }^{2}$ Y. Sumandiyo Hadi. 2003. Aspek-aspek Dasar Koreografi Kelompok. Yogyakarta: Elkaphi. p. 69-70.
}

MARHAROAN BOLON: KOREOGRAFI YANG TERINSPIRASI DARI PESTA ADAT MASYARAKAT BATAK SIMALUNGUN

gerak-gerak yang dipelajari atau ditemukan sebelumnya, tetap ciri spontanitas menandai hadirnya improvisasi. ${ }^{2}$ Improvisasi digunakan untuk memahami ketubuhan penari dengan penari lainnya, dan penari terhadap penata tari. Dalam karya ini ada beberapa gerak yang tercipta karena penemuan secara spontanitas melalui tahap mencoba-coba.

\section{Komposisi}

Komposisi merupakan permainan gerak, ruang, dan waktu untuk menciptakan kesan yang atraktif dan bervariasi dengan penambahan unsur pendukung dalam tari seperti musik dan rias busana. Pada tahap ini merupakan tahap melakukan penyeleksian, pembentukan serta penyusunan gerak-gerak yang telah didapat dari hasil pencarian selama proses eksplorasi dan improvisasi. Komposisi juga merupakan tahap menyeleksi, menyusun, merangkai, menata gerak, serta mengevaluasi menjadi koreografi. Hawkins dalam bukunya yang berjudul Moving From Within: A New Method For Dance Making. ${ }^{3}$ Dari pendapat tersebut, penata juga melakukan evaluasi dalam menciptakan karya "Marharoan Bolon".

\footnotetext{
${ }^{3}$ Y. Sumandiyo Hadi. 2003. Aspek-aspek Dasar Koreografi Kelompok. Yogyakarta: Elkaphi. p. 79.
} 


\section{Realisasi Proses dan Hasil Penciptaan}

\section{Introduksi}

Bagian introduksi dimulai dengan menyuguhkan musik bernuansa Batak Simalungun dalam tempo lambat dan melodis dilanjutkandengan menceritakan dalam bentuk visual ringkasan dari dimulainya menanam padi, ritual hingga pesta Rondang Bittang. Para petani wanita saling bergotong royong dan bergembira pada saat pesta Rondang Bittang, dengan gerakan-gerakan kontras dengan menghadirkan 4 penari pada dengan menggunakan setting trap.

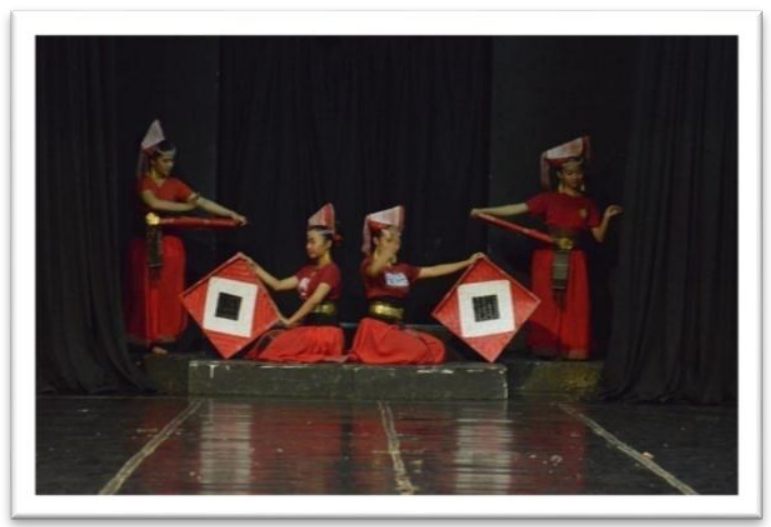

Gambar 5: Penari berada di belakang backdrop dengan level rendah dan sedang. Sebagai awal introduksi. (Foto: Pgraphproject, 2018, di Auditorium tari)

\section{Adegan I}

Pada adegan pertama, penari bergerak rampak dengan mengembangkan motif gerak Mangunje Mangodak, dan nahei kaki. Gerak tegas, mengayun dan cepat menjadi dominan pada adegan ini. Pada bagian adegan 1 para penari bergerak dari level rendah kemudian penari memecah fokus bergerak dengan level sedang dan tinggi ke arah depan. Pada bagian adegan ini juga memvisualisasikan wanita yang sedang menanam benih padi di sawah. Pada adegan ini lebih banyak pengembangan motif gerak Mangunje Mangodak dan nahei $k a k i$, esensi menyilang kemudian membuka dan saling mengisi dari motif tersebut. Formasi di titik lemah juga terdapat pada adegan ini.

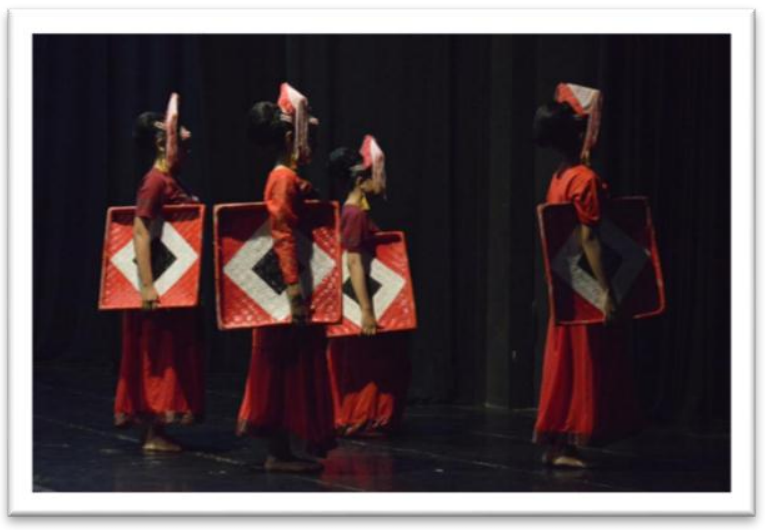

Gambar 6: Pola lantai berbentuk belah ketupat menghadap serong kanan sebagai awal dari bagian I yaitu adegan menanam padi (Foto: Pgraphproject, 2018, di Auditorium Tari)

\section{Adegan II}

Pada adegan ini, 2 penari tetap berada di area pementasan atau on stage. Permainan lighting pada adegan ini sangat terlihat. Gerak pengulangan atau repetisi dan gerak-gerak menyilang menjadi ciri khas pada adegan ini. Adegan II terdapat bagian pencahayaan dengan focusklight, menggerakkan motif asli Mangunje Mangodak, dan nahei kaki, dan 
JOGED: Jurnal Seni Tari p-ISSN 1858-3989 | e-ISSN 2655-3171

dengan adegan proses benih padi yang mulai tumbuh hingga saatnya memanen padi. Lalu diakhir dari adegan ini saat ketika ada delapan penari membentuk pola lantai X (tanda silang).

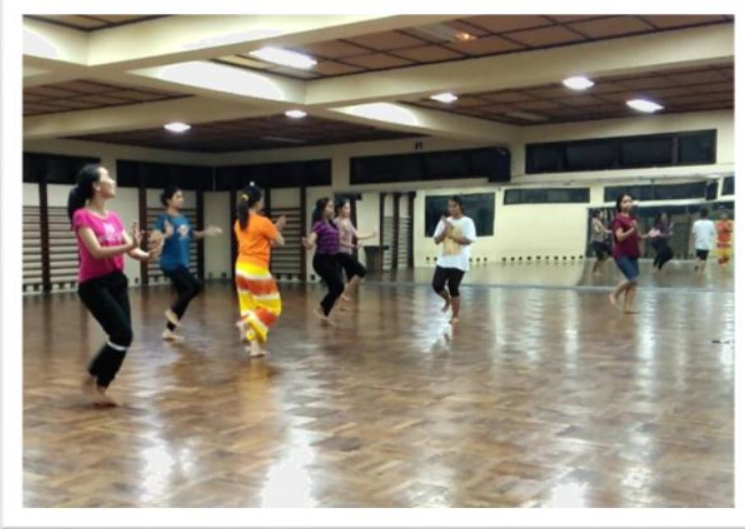

Gambar 7: Pola lantai berbentuk X sebagai akhir dari adegan II (Foto: Desy Wulan Pita Sari Damanik: 2018 di Studio 2)

\section{Adegan III}

Pada adegan ini diawali dengan wanita-wanita yang akan melakukan ritual mulai dari pembersihan hingga berdoa kepada nenek moyang sebelum melakukan pesta Rondang Bittang. Adegan III penari bergerak bersama-sama seperti pada adegan I, dengan membentuk pola lantai melingkar dan 1 penari di tengah. Adegan ini diakhiri dengan doding (nyanyian) dari penari.
MARHAROAN BOLON:

KOREOGRAFI YANG TERINSPIRASI

DARI PESTA ADAT MASYARAKAT BATAK SIMALUNGUN

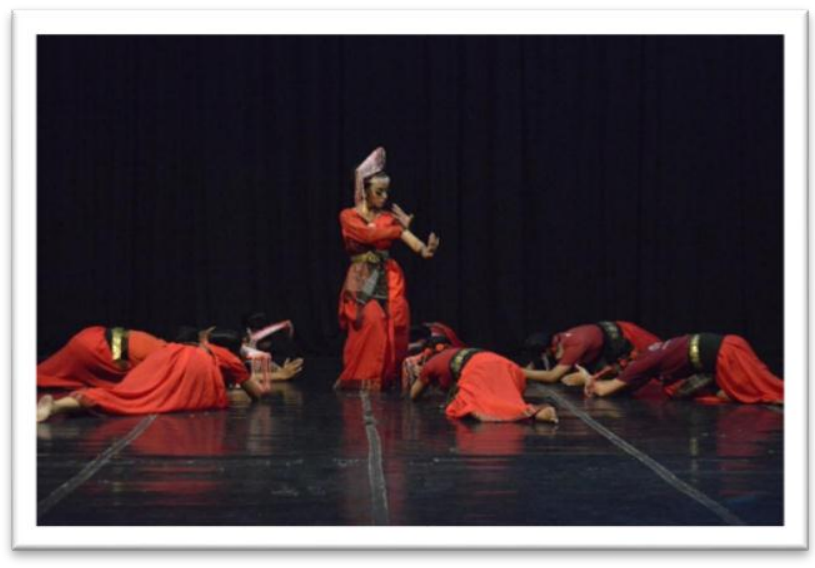

Gambar 8: Pola lantai berbentuk lingkaran sebagai awal dari bagian III yaitu adegan ritual (Dokumentasi: Pgraphproject: 2018, di Auditorium tari)

\section{Adegan 4 (Ending)}

Pada adegan 4 properti Anduri (tampah berbentuk persegi khas Simalungun) seperti yang dimunculkan pada bagian introduksi, dimunculkan kembali. Pada adegan ini suasana keramaian pesta Rondang Bittang dimunculkan dengan gerakan saling mengisi, gerakan pengembangan dari gerak menyilang. Diawali dengan menggerakkan motif Mangunje Mangodak dan kedelapan penari menyebar. Permainan lighting pada bagian ini sangat terlihat. Gerak pengulangan atau repitisi menjadi dominan pada bagian ini. Pada akhir adegan ini penari melakukan gerak-gerak gotong royong dengan memunculkan suasana gembira dan meriah, karena di sini puncaknya pesta Rondang Bittang. Kegiatan yang dilakukan pada pesta Rondang Bittang antara lain menumbuk padi, 
bernyanyi, dan menari. Pada adegan ini 4 penari sebagi petani yang sedang menari, 2 penari menumbuk padi dan 2 penari lagi bernyayi doding (syair) yang dinyanyikan awal menuju adegan 4.

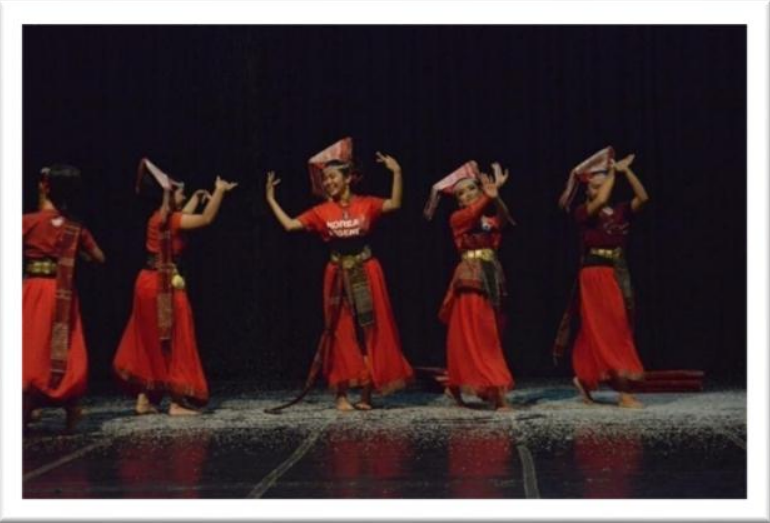

Gambar 9: Pola lantai broken sebagai akhir dari bagian IV yaitu adegan pesta panen

(Foto:Pgraphproject: 2018, di Auditorium tari)

1. Motif Mangunje mangodak: motif ini diawali dengan gerakan kedua tangan menyilang di depan dada dan kedua tangan di sisi kiri dan kanan dengan membolakbalikkan telapak tangan.

2. Motif Membuka roha: gerakan timpuh badan condong ke depan sambil mangodak ke kiri dan ke kanan

3. Motif nahei kaki: gerakan silang kaki sambil memegang suri- suri yang diikatkan di pinggang

4. Motif badan manduda: gerakan badan seperti orang yang sedang menumbuk padi menggunakan losung/lesung.
5. Motif ondok: gerakan dengan menekukkan kaki ke depan seperti hendak menjatuhkan pinggul dan kembali tegak, dilakukan secara berulang-ulang.

6. Motif Urdot: gerakanmenggenjotkan tubuh dengan menekuk lutut lalu menegakkan kembali.

7. Motif Manapih Anduri: menggerakkan properti anduri ke atas dan ke bawah

8. Motif Mangirik Anduri: gerakan menggetarkan properti.

9. Motif Sombah: gerakan pergelangan tangan ke depan belakang dengan merapatkan jari-jari seperti orang menyembah.

10. Motif Kerja Sama : gerakan saling bersentuhan dan interaksi secara berpasangan.

\section{PENUTUP}

Karya "Marharoan Bolon" adalah sebuah karya tari yang dilatarbelakangi ritual pesta Rondang Bittang sebagai salah satu ucap syukur keberhasilan dan merayakan panen yang berlimpah dalam budaya masyarakat Batak Simalungun. Karya ini disajikan dalam bentuk koreografi kelompok, didukung delapan penari, berjenis kelamin perempuan. Karya ini terinspirasi juga dari tari Manduda yang menggambarkan petani wanita, dan pola gerak yang simetris. 
Pesta Rondang Bittang memiliki filosofi kerja sama dan saling gotong royong terhadap sesama makhluk hidup. Berdasarkan makna tersebut, masyarakat Simalungun memegang teguh prinsip Marsiolop Ari artinya saling memberi waktu membantu di ladang lain, begitu pula sebaliknya. Segala kegiatan adat masyarakat Simalungun tidak dapat berjalan dan terlaksana apabila tidak saling kerja sama dan bergotong royong.

\section{DAFTAR SUMBER ACUAN}

\section{A. Sumber Tertulis}

Basyarshah, Tuanku Luckman Sinar. 2009. Lintasan Adat dan Budaya Simalungun. Medan:Forkala Sumut

Damanik, Ramlan, Baharuddin, dkk. 1997. Limbaga (Peribahasa) Bahasa Simalungun. Jakarta: Pusat Pembinaan dan Pengembangan Bahasa Departemen Pendidikan dan Kebudayaan.

Dewantara, Agustinus W. 2017. Alangkah Hebatnya Negara Gotong Royong (Indonesia dalam Kacamata Soekarno). Yogyakarta: PT KANISIUS.

Dharmansyah, Corry Siagian, dkk.1986. Dampak Modernisasi Terhadap Hubungan Kekerabatan Daerah Sumatera Utara. Jakarta: Departemen Pendidikan dan Kebudayaan
Hadi, Y.Sumandiyo. 2014. Koreografi Bentuk-Teknik-Isi. Yogyakarta: Cipta Media bekerjasama dengan ISI Yogyakarta.

Hadi, Y.Sumandiyo. 2003. Aspek-aspek Dasar Koreografi Kelompok. Yogyakarta: eLKAPHI.

Harahap, Irwansyah. 2010. Hata Ni Debata Etnografi KebudayaanSpiritualMusikal Parmalim Batak Toba.Medan:Pusat Warisan Seni Sumatera

Hawkins, Alma M. 1988. Creating Through Dance. New Jersey: Princeton Book Company. Diterjemahkan Y.Sumandiyo Hadi. 1990. Mencipta Lewat Tari. Yogyakarta: Institut Seni Indonesia Yogyakarta.

Heriyawati, Yanti. 2016. Seni Pertunjukan dan Ritual. Yogyakarta: Ombak

Humphrey, Doris. 1977. The Art of Making Dance. New York: Grove Press. Diterjemahkan oleh Sal Murgiyanto. 1983. Seni Menata Tari. Jakarta: Dewan Kesenian Jakarta

Kadir, Abdul, Ramelan, dkk. Album Sejarah Seni Budaya Batak Simalungun dan Toba.Jakarta: kebudayaan Departemen Pendidikan dan Kebudayaan Republik Indonesia.

Kozok, Uli. 2015. Surat Batak (Sejarah perkembangan Tulisan Batak Berikut Pedoman Menulis Aksara Batak dan Cap Si Singamangaraja XII). Yogyakarta: Kepustakaan Populer Gramedia 
Malau, Gens G. 1994. Dolok Pusuk Buhit (Pelajaran Menulis Aksara Batak). Jakarta: Balai Pustaka

Malau, Waston, D. Sinaga, dkk. 1985. Upacara Tradisional Yang Berkaitan Dengan Peristiwa Alam Dan Kepercayaan Daerah Sumatera Utara. Jakarta: Departemen Pendidikan dan Kebudayaan.

Marah, Risman.1983. Album Seni Budaya Sumatera Utara Cultural Album Of North Sumatra. Jakarta: Departemen Pariwisata dan Kebudayaan

Martono, Hendro. 2012. Koreografi Lingkungan Revitalisasi Gaya Pemanggungan dan Gaya Penciptaan Seniman Nusantara. Yogyakarta: Cipta Media

Martono, Hendro 2015. Ruang Pertunjukan dan Berkesenian. Yogyakarta: Cipta Media.

Purba, Bukit dalam Elizabeth Gurning dan Djoko Mudji Rahardo. 2003. Tanah Simalungun. Jakarta: Badan Pengembangan Kebudayaan dan Pariwisata.

Purba, Krismus. 2002. Opera Batak Tilhang Serindo Pengikat Budaya Masyarakat Batak Toba di Jakarta. Yogyakarta: Kalika

Saragih, J. E. Pustaha Laklak No. 252 Museum Simalungun (Salinan dan terjemahan). Jakarta: Proyek Pengembangan Media Kebudayaan Ditjen Kebudayaan Departemen P \& K RI.
Saragih, J. M. 1986. Peralatan Hiburan dan Kesenian TradisionalDaerah Sumatera Utara. Sumatera Utara: Inventarisasi dan Dokumentasi Kebudayaan Daerah

Sedyawati, Edi, Sal Murgiyanto, dkk. 1986. Pengetahuan Elementer Tari dan Beberapa Masalah Tari. Jakarta: Direktorat Kesenian Proyek Pengembangan Kesenian Jakarta Departemen Pendidikan dan Kebudayaan.

Smith, Jacqueline. 1985. Komposisi Tari: Sebuah Petunjuk Praktis Bagi Guru. Terjemahan Ben Suharto. Yogyakarta: IKALASTI Yogyakarta.

Soedarsono, R.M. 2002. Seni Pertunjukan Indonesia Di Era Globalisasi.

Yogyakarta: Gadjah Mada University Press.

Soedarsono, R.M 2003. Seni Pertunjukan Dari Perspektif Politik, Sosial, dan Ekonomi. Yogyakarta: Direktorat Jendral Kebudayaan.

Suwando, Bambang. 1978. Adat dan Upacara Perkawinan Daerah Sumatera Utara. Sumatera Utara: Pencatatan dan Penelitian Kebudayaan Daerah

Tambunan,E.H.1982. Sekelumit Mengenai Masyarakat Batak Toba

Dan

Kebudayaannya Sebagai Sarana Pembangunan.

Bandung: 


\section{TARSITO}

Turner, Margery J. 1976. New Dance: Approaches to nonliteral Choreography. London: University of Pittsburgh Press. Diterjemahankan Y.Sumandiyo Hadi. 2012. New Dance: Pendekatan Koreografi Nonliteral. Yogyakarta: ISI Yogyakarta.

Vergouwen, JC. 2004. Masyarakat dan Hukum Adat Batak

Toba.

Yogyakarta: LKiS Yogyakarta.

Yudiaryani, Bambang Pudjasworo, dkk. 2017. Karya Cipta Seni Pertunjukan. Yogyakarta: JB PUBLISHER bekerjasama dengan FSP ISI Yogyakarta.

\section{B. Sumber Lisan}

Edy Taralamsyah Saragih, Sumatera utara, 21 desember 1950, seniman

Efrin Girsang, Pematang Siantar, 17 april 1995, Seniman.

Laura Tyas Avionita Sinaga, Pematang Siantar, 27 Januari 1997, seniman dn penari Simalungun.

Mardi Purba Dasuha, Pematang Siantar, 05 Desember 1994, Seniman

Rahmat Pratomo, Kisaran, 22 Desember 1996, penari tari Manduda.

Rizky Firdalia pipin, Kisaran, 02 September 1993, penata busana Batak.
Siti Rahmah, Sumatera Utara, 28 September 1969, dosen pengampu mata kuliah tari Batak Simalungun di Universitas Negeri Medan.

\section{Videografi}

Video "Mangodakodak" karya Desy Wulan Pita Sari Damanik pada tahun 2017, koleksi Desy Wulan Pita Sari Damanik

Video“Kepret Kamale"karya Dhea Indres Narulitapada tahun 2017, koleksi Dhea Indres Narulita.

Video "Hahomion $\mathrm{Na}$ Tolu" karya Rines Onyxi Tampubolon pada tahun 2017, koleksi Rines Onyxi Tampubolon

\section{Webtografi}

https://id.wikipedia.org/wiki/suku_simalung un

https://kamusbataksimalungun.wordpress.co $\mathrm{m} / \mathrm{b} /$ (Marhaposan Agustinus Purba. Diunduh pada Senin, 18 Februari 2013)

https://shavainistia.wordpress.com/2016/06/ 08/tarian-simalungun/ (Diposkan pada Juni 8, 2016)

http:// lagu

Simalungunmp3.blogspot.co.id/20 12/12/tari-haroan-bolon.html/m=1 (Arnold Teguh Silalahi. Sabtu, 29 Desember. 2012)

http://saragihgaringging.blogspot.co.id/2010/11 /taralamsyah-saragih-sangmaestro-itu.html (penulis:M. Muhar Omtatok. Diunduh padaMinggu, 03Deseember2017) 